\title{
Helen Salisbury: Just say sorry
}

\author{
Helen Salisbury GP
}

Oxford

We're all human, and we all make mistakes. It's said that traditional Persian weavers introduced deliberate errors into their work, believing that it was blasphemous to strive for perfection, which was solely a property of the divine.

Doctors' errors are not deliberate, but they happen. We spend time helping students and trainees to find the courage and the right words to say to patients, "I'm sorry, I made a mistake" and to work with them to salvage the situation. We build systems with multiple checks so that, if one individual makes an error, someone else on the team will pick it up. I'm grateful to the local pharmacists who check my prescribing and pick up any mistakes before harm is done.

It's hard to admit to ourselves that we've fallen short. We really want to live up to our self-image of competent, caring doctors who, although busy, are in control and on top of our work. It can be harder to admit to patients that something has gone wrong and that it's our fault. However, this is one of our professional obligations-the duty of candour. ${ }^{1}$

This week Sweden's state epidemiologist, who has overseen the country's coronavirus response, admitted that too many Swedes had died. ${ }^{2}$ He stood up and said that, if the Swedish government had known at the beginning of the pandemic what we know now, the strategy would have been different.

When we compare our own political leaders it's difficult not to be embarrassed. In the face of incontrovertible evidence in the form of mortality statistics, they persist in telling us that they did the right things, at the right time, according to the scientific advice.

On 3 June more covid-19 deaths occurred in the UK than in the whole of the rest of the EU combined. ${ }^{3}$ Although figures from the Office for National Statistics showed 39000 new infections a week in England from 26 April to 30 May, and the death rate is as high now as when the lockdown began, most of the measures to control infection have been thrown to the wind. ${ }^{4}$ By gathering in the House of Commons when they were perfectly able to work from home, MPs are leading by bad example, and the nation is following. This week I overheard a visitor to my surgery suggest that, "now that lockdown is over, the queues will be horrendous."

Four members of the government's scientific advisory committee have now broken ranks, voicing concern that lifting restrictions too soon risks a second wave of infection. We desperately need some honesty and humility from our leaders, but all we get is bluster, hubris, and massaged statistics. ${ }^{5}$ If they could just admit to their mistakes and acknowledge the dangerous mess we're in, we could perhaps find a way to the single digit death figures our neighbours in Europe have achieved.

Competing interests: See www.bmj.com/about-bmj/freelance-contributors. Provenance and peer review: Commissioned; not externally peer reviewed.

1 General Medical Council. Openness and honesty when things go wrong: the professional duty of candour. https://www.gmc-uk.org/ethical-guidance/ethical-guidance-for-doctors/ candour---openness-and-honesty-when-things-go-wrong.

2 Coronavirus: Sweden's Tegnell admits too many died. BBC News 2020 Jun 3. https:// www.bbc.co.uk/news/world-europe-52903717.

3 Tidey A. UK records more new COVID-19 deaths than entire EU combined. EuroNews 2020 Jun 4. https://www.euronews.com/2020/06/04/uk-records-more-one-day-covid-19fatalities-than-eu27-combined.

4 Office for National Statistics. Coronavirus (COVID-19) roundup. Jun 2020. https://www. ons.gov.uk/peoplepopulationandcommunity/healthandsocialcare/conditionsanddiseases/ articles/coronaviruscovid19roundup/2020-03-26.

5 Boseley S. Statistics watchdog: ministers still misleading public on coronavirus tests. Guardian 2020 Jun 2. https://www.theguardian.com/world/2020/jun/02/statistics-watchdogministers-still-misleading-public-on-coronavirus-tests\#maincontent.

Published by the BMJ Publishing Group Limited. For permission to use (where not already granted under a licence) please go to http://group.bmj.com/group/rights-licensing/ permissions 